\title{
Питання психології
}

УДК 159.923 .2

DOI: $10.33099 / 2617-6858-20-57-4-44-51$

Козак О. Ю. Уманський державний педагогічний університет імені Павла Тичини https://orcid.org/0000-0002-8164-0733

\section{ВИРОБНИЧА ПРАКТИКА ЯК ПСИХОЛОГІЧНИЙ ІНСТРУМЕНТ АДАПТАЦЇ̈ МАЙБУТНІХ ПЕДАГОГІВ ДО ПРОФЕСІЙНОЇ ДІЯЛЬНОСТІ}

Стаття присвячена обгрунтуванню основних підходів до успішної адаптації майбутніх педагогів до професійної діяльності в умовах закладу вищзої освіти. Розкриваються процесуальнозмістовні аспекти виробничої практики як психологічного інструменту подолання психологічних перешкод на шляху до адаптації майбутніх педагогів до професійної діяльності.

Ключові слова: адаптація; майбутні педагоги; виробнича практика; професійна діяльність; заклад вищчої освіти.

\section{Вступ.}

Актуальність теми. Сучасна школа має гостру потребу у молодих педагогах, здатних адекватно реагувати на зміни освітньої ситуації, специфіку педагогічних систем, нові умови професійної діяльності $[1 ; 2 ; 3 ; 4 ; 5]$. Відомо, що закінчення 3ВО, отримання диплому ще не означає, що педагог-початківець вже $є$ професіоналом. Його чекає довгий період адаптації інкорпорування у професію у нелегких сучасних економічних i соціальнополітичних умовах. Тому підготовка студентів до професійної діяльності в умовах зростаючих вимог освітньої системи, здатних успішно адаптуватися у сучасних соціокультурних умовах, стає усе більш актуальною.

Як показують результати досліджень, сучасні тенденції, на жаль, мають виражений негативний характер, бо у сфері кадрового забезпечення у системі вищої освіти тривожним є поступове збільшення середнього віку педагогів за рахунок збільшення кількості осіб передпенсійного віку. Небагато випускників педагогічних ЗВО йдуть працювати за фахом. Пов'язано це із тим, що інститути освіти, які сприяють соціально-професійній адаптації педагогівпочатківців до норм i вимог педагогічної професії, не враховують суперечності, які супроводжують цей процес у молодих педагогів, вплив зовнішніх чинників, що перешкоджають їхній соціальнопрофесійної адаптації. Як закономірний результат, в Україні спостерігається зниження престижу професії педагога, обумовлене зниженням престижу освіти у суспільстві і низьким рівнем його матеріального добробуту.

Мета статті - обгрунтування основних підходів до успішної адаптації майбутніх педагогів до професійної діяльності в умовах 3ВО.

Завдання статті - розкрити процесуально-змістовні аспекти виробничої практики як психологічного інструменту подолання психологічних перешкод на шляху до адаптації майбутніх педагогів до професійної діяльності.

Теоретичне підгрунтя.

Професійна адаптація - це процес i результат пристосування індивіда до вимог професії, засвоєння ним професійних i соціальних норм поведінки, необхідних для виконання трудових функцій [6, 272]. Професійна адаптація здійснюється шляхом звикання молодих фахівців до змісту i режиму праці, до вимог i стилю роботи, відносин у трудовому колективі. Вона визначається рівнем оволодіння професійними навичками, формуванням професійно необхідних якостей особистості і відображає розвиток стійкого позитивного ставлення до обраної професії [7].

Аналіз численних досліджень із цієї 


\section{Питання психології}

проблеми (Г.В. Безюлєва, С.Ф. Зеєр, О.М. Недосека, С.М. Тарасова, Л.С. Солянкина, О.С. Хамзяєва, Л.О. Щелкунова та ін.) дозволяє зробити висновок, що професійна адаптація студента являє собою єдність адаптації індивіда до фізичних умов професійного середовища (психофізіологічний аспект), адаптації до професійних завдань, виконуваних операцій, професійної інформації і т. п. (професійний аспект) та адаптації особистості до соціальних компонентів професійної середовища (соціальнопсихологічний аспект).

\section{Методи дослідження.}

Для досягнення мети i реалізації завдання дослідження було використано низку теоретичних та емпіричних методів: теоретичні - аналіз, синтез, узагальнення, порівняння і систематизація українських i зарубіжних наукових розробок у психологічних джерелах із проблеми адаптації майбутніх фахівців до професійної діяльності; емпіричні - тестування, опитування для дослідження психологічних особливостей становлення структурних компонентів i механізмів досліджуваного психологічного утворення.

Результати і обговорення.

Аналіз літератури показує, що існують різні точки зору щодо початку процесу професійної адаптації. Одні дослідники вважають, що процес професійної адаптації починається безпосередньо на виробництві, інші стверджують, що початок цього процесу закладається ще під час навчання в установі професійної освіти. Професійна адаптація починається у 3ВО, де студент отримує необхідні професійно знання, вміння, навички, набуває досвід вирішення типових професійних завдань. Крім цього, у цей період відбувається формування професійної спрямованості особистості, переструктуризація i закріплення професійних мотивів, формуються професійно значущі якості.

Процес адаптації студентів до професійної діяльності проходить у три етапи. Перший із них - знайомство студентів iз професійною діяльністю. Цей період характеризується тим, що студенти отримують початкові знання про обрану професію, iii значущість i професійні навички під час практичних занять. Другий етап - робота студентів в освітніх установах у складі педагогічного колективу. Третій етап - робота випускників у школі після закінчення 3ВО.

Очевидно, що професійна адаптація майбутніх фахівців здійснюється в процесі практики студентів до професійної діяльності, яка, на думку дослідників, є важливим компонентом професійного навчання студентів у ЗВО [6]. У словникудовіднику української психологічної термінології «практика» трактується як цілісна система операцій, структура якої містить потреби, цілі, мотиви, діяльність, предмет, на який спрямована ця діяльність, способи, за допомогою яких досягається мета i результат діяльності [9]. Таким чином, у структурі професійної підготовки майбутніх педагогів практика $є$ провідною ланкою, що забезпечує інтеграцію теоретичних знань студентів 3 їхньою практичною діяльністю. Специфікою діяльності в процесі педагогічної практики $є$ те, що у ній здійснюється ідентифікація із професійною діяльністю.

Л.О. Щелкунова, проаналізувавши звіти студентів після проходження ними педагогічної практики, виокремлює такі труднощі: слабке володіння технологією цілепокладання у педагогічному процесі; недостатній розвиток аналітичних вмінь; проблеми у взаємодії із батьками та спілкуванні зі школярами [10]. Є.Ф. Зеєр зазначає, що причинами труднощів, як правило, є: недолік або несвоєчасність отримання необхідної інформації, що дозволяє зорієнтуватися у новій ситуації $\mathrm{i}$ знайти правильне рішення; відсутність необхідного професійного досвіду i кваліфікації; необхідність вирішувати одночасно кілька дуже важливих завдань: вивчати ситуацію, приймати рішення, виконувати свої нові обов'язки, встановлювати корисні контакти, освоювати 


\section{Питання психології}

нові елементи діяльності, особливо ретельно будувати свою поведінку; недостатнє уявлення про норми професійної поведінки; необхідність формувати певну позитивну думку оточуючих про себе; постійне перебування у зоні оцінювання [6].

Зіткнення студентів із різними труднощами під час проходження практики у школі, невідповідність професійної діяльності їхнім очікуванням може викликати кризу професійних очікувань. Напруженість роботи характеризується такими висловлюваннями, як «почуття непотрібності», «нічого не виходить», «падіння із небес на землю» i т. п. Переживання розбіжності професійної діяльності з очікуваннями викликає зміну професійної позиції, а незадоволеність виконуваною діяльністю змінює соціальнопрофесійну спрямованість [3; 11]. Таким чином, основною причиною настання кризи на етапі професійної адаптації є розбіжність реального професійного життя зі сформованими уявленнями та очікуваннями. Проведене О.О. Андрієнко дослідження, показало, що саме після проходження виробничої практики частина студентів розчаровується в обраній професії [12; 13]. А.О. Реан і Я.Л. Коломінський зазначають, що максимальна задоволеність обраною професією спостерігається у студентів першого курсу. Надалі цей показник неухильно знижується [14]. I.C. Кон акцентує увагу на тому, що в міру переходу студентів на старші курси ЗВО кількість тих із них, хто не задоволений обраною спеціальністю, не скорочується, а зростає [15]. Таку незадоволеність можна пояснити виявленням тіньових сторін майбутньої спеціальності, які раніше не помічалися, а розкриваються в ході проходження практик.

У дослідженні, присвяченому вивченню особливостей професійної адаптації майбутніх педагогів у період проходження виробничої практики у школі, взяли участь студенти УДПУ імені Павла Тичини у кількості 98 осіб у віці від 17 до 22 років. Для вивчення професійної адаптації студентів під час проходження виробничої практики використовувалися такі методики: анкета «Вивчення труднощів у роботі вчителя», «Анкета для виявлення стресових переживань, що виникають у педагогічній діяльності» (О.М. Чоросова, Р.Є. Герасимова), «Оцінка професійної спрямованості вчителя» (Є.І. Рогов), «Тестопитувальник для визначення рівня професійної спрямованості студентів» (Т.Д. Дубовицька).

Під час самооцінки студентами своєї педагогічної діяльності по анкеті «Вивчення труднощів у роботі вчителя» було відзначено такі труднощі: аналіз педагогічної діяльності: вміння проводити самоаналіз уроку (19,2\%), вміння проводити самоаналіз виховного заходу $(28,4 \%)$, вміння аналізувати якість знань і рівень вихованості учнів $(45,7 \%)$; планування: поурочні (14\%), виховної роботи $(42,1 \%)$, роботи із батьками $(71,3 \%)$; організація (особистої праці $(66,3 \%)$, навчальнопізнавальної діяльності учнів $(57,5 \%)$, позаурочної виховної роботи $(53,2 \%)$; контроль і корекція: самоконтроль і самокорекція $(73,0 \%)$, корекція знань учнів $(34,9 \%)$; володіння технологією сучасного уроку: постановка цілей уроку $(22,8 \%)$, вибір типу уроку (32,8\%), відбір головного, істотного в змісті навчального матеріалу $(12,3 \%)$, відбір методів і форм організації пізнавальної діяльності учнів (17,8\%).

Під час проходження практики студенти відчувають труднощі як 3 плануванням, організацією, проведенням уроків i позакласних заходів, так i зі спілкуванням зі школярами. В результаті застосування анкети, спрямованої на виявлення стресових переживань, що виникають у педагогічній діяльності, було виявлено, що у $16,5 \%$ студентів високий показник відповідного фактора «Відсутність перспективи», тобто вони, як педагоги, дивлячись у майбутнє, відчувають сумніву i безнадійність, тривогу, коли замислюються про свою роботу у школі, їм нецікаво освоювати нові знання із предмета. За іншими факторами («Фактор негативного 


\section{Питання психології}

впливу зовнішніх обставин», «Фактор втрати сенсу життя» $\mathrm{i}$ «Фактор відчуження») респондентів із високими показниками не виявлено. Можна сказати, що у цілому студенти-практиканти не перебувають у кризовому стані, вони можуть самостійно визначати свої життєві орієнтири, цікавитися новим, прагнути до саморозвитку.

Аналізуючи результати діагностики за методикою Т.Д. Дубовицької, можна зробити констатувати, що у $45,7 \%$ студентів виявлено високий рівень професійної спрямованості, що свідчить про їхні прагнення до оволодіння обраною професією, бажанні у майбутньому працювати і далі вдосконалюватися у ній. При цьому було також виявлено, що частина студентів бажає викладати лише у старших класах, робота у середній ланці школи їх не приваблює i викликає страх. У $18,5 \%$ майбутніх педагогів низький рівень професійної спрямованості, що характеризується вимушеним вчитися на конкретному факультеті, відсутністю інтересу до одержуваної професії i небажанням працювати по ній, ці студенти не бачать нічого хорошого для себе у педагогічній діяльності. Після діагностики студентів за допомогою методики С.I. Рогова на визначення професійної спрямованості педагога було виявлено, що у $21,0 \%$ респондентів високий рівень спрямованості на спілкування («Вчителькомунікатор»). Цьому типу властиві такі якості, як екстравертованість, товариськість, емоційність і пластичність поведінки, низька конфліктність, доброзичливість, здатність до емпатії, любов'ю до дітей. У $11,6 \%$ студентів-практикантів високий рівень спрямованості на організаторську діяльність («Вчитель-організатор»), що характеризується зібраністю, вимогливістю, волею, енергійністю. Основний напрямок діяльності педагога цього типу перебуває у площині позакласної роботи. У $16,4 \%$ студентів високі показники по спрямованості на просвітництво та високий інтелект («Вчитель-інтелігент»), для якої властиві висока загальна культура, безумовна моральність, принциповість. $14,7 \%$ опитаних орієнтовані на предмет, що викладається («Вчитель-предметник»), що характеризується спостережливістю, професійною компетентністю, прагненням до творчості, раціоналізмом, інтересом до наукової діяльності.

Домінуючими типами за цією методикою $є$ «Вчитель-комунікатор» (середнє значення по групі - 6,4 бала) i «Вчитель-інтелігент» (6,2 бали), тобто найважливішими факторами вибору педагогічної професії $\epsilon$ бажання спілкуватися, працювати із дітьми і потреба у саморозвитку. Також близькі до цих значень показники за типом «Вчительпредметник» (5,2 бала). Було виявлено, що студентів не приваблює діяльність педагога, пов'язана із позакласної роботою, це є для них найменш привабливим фактором $\mathrm{y}$ педагогічній професії («Вчительорганізатор» - 3,7 бала). Також було визначено, що усього у $23,8 \%$ першокурсників виражена моноспрямованість - спрямованість на один тип. $\mathrm{У} \quad 36,4 \% \quad$ представлена поліспрямованість, тобто вираженість декількох типів. Переважним серед типів поліспрямованого є «Вчитель-комунікатор» - «Вчитель-предметник» - «Вчительінтелігент».

Таким чином, студенти, які навчаються за педагогічним профілями підготовки, позитивно ставляться до професії педагога, у них виявлено спрямованість на роботу із дітьми, достатньо велика частина студентів після проходження практики планує працювати в системі освіти, не зважаючи на усі складнощі педагогічної праці. Дослідження показало, що студенти, проходячи практику у школі, відчувають труднощі не стільки в аспекті проведення уроків, скільки у встановленні контакту із дітьми, у виробленні оптимальної стратегії і тактики спілкування із класом, невмінні вибудовувати взаємини і перебудовувати їх у залежності від ситуації, невміння знаходити нестандартні прийоми у 


\section{Питання психології}

вирішенні проблемних завдань і т. п. Усе це заважає правильно організовувати плідний освітній процес. Щоб адаптація студентів до професійної діяльності була більш ефективною, необхідна їхня системна підготовка до трудової діяльності, що містить заходи, спрямовані на формування професійної культури, прищеплення цінностей і норм професійної середовища; цикли соціально-психологічних тренінгів впевненої професійної поведінки; психологічний супровід кар'єри студентів педагогічного 3ВО.

У цій ситуації ЗВО дійсно може реально допомогти. Саме ЗВО може створити умови для самої активної участі студентів у різних сферах діяльності: професійній, громадській, культурній. Включення студентів у роботу різних професійних, творчих i наукових об'єднань та співтовариств (молодіжні центри, академії лідерів, постійно діючі спеціалізовані школи, «бізнес-інкубатори» і т. п.) забезпечує накопичення різноманітного досвіду i, відповідно, можливість вибору різних варіантів і моделей педагогічної кар'єри.

ЗВО може ініціювати і заохочувати створення науково-дослідних робочих груп у межах підготовки грантових заявок, великих науково-практичних конференцій, форумів. У таких групах, куди, крім викладачів i фахівців, включаються i студенти, діяльність організована за проектним принципом. Саме навчання 3 окремих дисциплін (як правило, профільних або спеціальних) може бути організовано як розробка i захист проекту (наприклад,у межах навчання психології управління, студентські мікрогрупи моделюють свою компанію, розробляють іiі місію, описують цілі, завдання, конкурентні переваги на ринку, обгрунтовують кадрову політику, пропонують систему мотивації). 3 іншого боку, важливу роль в процесі інкорпорування у професію відіграє безперервна педагогічна практика студентів у базових виховних установах.

\section{Висновки.}

Саме педагогічна практика має великі можливості для формування внутрішньої установки на педагогічну професію. В процесі практики інтенсифікується процес професійного становлення майбутнього педагога, його самоосвіти і самовиховання, здійснюється перевірка ступеня професійної підготовленості та придатності до педагогічної діяльності, рівня педагогічної спрямованості. Діяльність студентів під час практики $є$ аналогом професійної діяльності педагога, яка $\epsilon$ адекватною змістом i структурою педагогічної діяльності та організовується у реальних умовах нової української школи. Вона характеризується тим же різноманіттям відносин (з учнями, їхніми батьками, вчителями, студентами) i функцій, що і діяльність вчителя. Вже із молодших курсів завдяки педагогічній практиці у студентів з'являється можливість перевірки та оцінки себе як майбутнього педагога, своєї професійної підготовки і придатності. Під час проходження практики студенти організовують освітній процес, створюють умови для реалізації потенційних можливостей учнів, керують їхнім розвитком, взаємодіють із батьками, тобто виконують ті ж обов'язки, що i досвідчені педагоги. Але ситуація може ускладнюватись тим, що практиканти, опинившись у новому середовищі, стикаються із незвичними ситуаціями, відчувають власну неспроможність, побоюються критики своїх наставників, постійно хвилюються, бояться що-небудь не встигнути, забути, упустити, соромляться звернутися за допомогою до досвідчених педагогів. Усе це призводить до зайвої напруженості, тривожності i незадоволеності своєю діяльністю. Щоб цього не сталося, педагогу необхідна цілеспрямована допомога із боку ЗВО, яка полягає в отриманні необхідної методичної та психолого-педагогічної інформації [1]. 


\section{Питання психології}

\section{Список використаних джерел}

1. Галус О.М. Активна професійна адаптація студентів як педагогічна проблема [Електронний ресурс] /О.М. Галус// Педагогічний дискурс. - 2007. - Вип. 1. - С.35-40. Режим доступу: http://nbuv.gov.ua/UJRN/peddysk $2007 \quad 19$.

2. Горбунова Н.В. Профессиональная адаптация будущих учителей и молодых специалистов к педагогической деятельности / Н.В. Горбунова// Гуманитарные науки. - 2019. - №3. - С. 38-44.

3. Котова С.А. Адаптация в должности и освоение профессии учителя /С.А. Котова// Народное образование. - 2010. - №8. - С. 121-127.

4. Скоробогатова Ю.В. Особенности эмоционального выгорания студентов педагогического вуза и его профилактика с помощью тайм-менеджмента /Ю.В. Скоробогатова// Перспективы науки и образования. - 2019. - №2(38). - С. 284-294.

5. Слепцова М.В., Попова О.Н. Адаптация будущих учителей технологии к профессиональной деятельности /М.В. Слепцова, О.Н. Попова// Учебно-методическое пособие для самостоятельной работы студентов, обучающихся по магистерской программе «Профессиональное образование». Воронеж: Изд-во ВГПУ. - 2014. - 76 с.

6. Зеер Э.Ф. Психология профессий / Э.Ф. Зеер. - М.: Академический Проект; Екатеринбург: Деловая книга. - 2003. - 336 с.

7. Безюлева Г.В. Психолого-педагогическое сопровождение профессиональной адаптации учащихся и студентов / Г.В. Безюлева. - М.: НОУ ВПО Московский психолого-социальный институт. - 2008. - $320 \mathrm{c}$.

8. Тархан Л.З. Дидактическая компетентность инженера-педагога: теоретические и методические аспекты / Л.3. Тархан. - Симферополь: КРП «Издательство «Крымучпедгиз». - 2008. - 424 с.

9. Болтівець С.І. Українська психологічна термінологія: словник-довідник / укл. С.І. Болтівць, Н.В. Слободяник, М.-Л.А. Чепа, Н.В. Чепелєва. - К.: ДП «Інформаційно-аналітичне агентство». - 2010. -302 c.

10. Щелкунова Л.А. Проблемы профессиональной адаптации студентов на педагогической практике [Электронный ресурс] / Л.А. Щелкунова. URL: https://cyberleninka.ru/article/n/problemyprofessionalnoy-adaptatsii-studentov-na-pedagogicheskoy-praktike (дата обращения 12.07.18).

11. Даниленко О.И., Носова А.С. Экзистенциальная исполненность и социальнопсихологическая адаптированность как предикторы субъективного благополучия студентов /О.И. Даниленко, А.С. Носова// Перспективы науки и образования. - 2020. - №4(46). - С. 315-325.

12. Андриенко О.А. Профессиональная адаптация студентов вуза в период прохождения производственной практики /О.А. Андриенко// Перспективы науки и образования. Международный электронный научный журнал. - 2018. - №4(34). - С. 84-88. Режим доступа pnojournal.wordpress.com/archive18/18-04.

13. Андриенко О.А. Исследование удовлетворенности студентов избранной профессией /О.А. Андриенко// Психология, социология и педагогика. - 2016. - №7. [Электронный ресурс]. URL: http://psychology.snauka.ru/2016/07/7010 (дата обращения: 07.06.2018).

14. Реан А.А., Коломинский Я.Л. Социальная педагогическая психология / А.А. Реан, Я.Л. Коломинский. - Питер Ком. - 1999. - 416 с.

15. Кон И.С. В поиске себя: Личность и ее самосознание. И.С. Кон. - М.: Политиздат. - 1984. $335 \mathrm{c}$.

\section{References}

1. Galuc O.M. (2007) Aktyvna profecijna adaptacija ctudentiv jak pedagogichna problema [Active professional adaptation of students as a pedagogical problem] [Elektronnyj recurc] /O.M. Galus// Pedagogichnyj dyckurc. - Vyp. 1. - C. 35-40. Rezhym doctupu: http://nbuv.gov.ua/UJRN/peddysk_2007_1_9 (in Ukrainian).

2. Gorbunova N.V. (2019) Profeccional'naja adaptacija budushhix uchitelej i molodyx cpecialictov k pedagogicheckoj dejatel'nocti [Professional adaptation of future teachers and young specialists to pedagogical activity] / N.V. Gorbunova// Gumanitarnye nauki. - №3. - S. 38-44 (in Russian).

3. Kotova S.A. (2010) Adaptacija v dolzhnosti i osvoenie professii uchitelja [Adaptation in position and mastering the profession of a teacher] /S.A. Kotova// Narodnoe obrazovanie. - №8. - S. 121-127 (in Russian). 


\section{Питання психології}

4. Skorobogatova Ju.V. (2019) Osobennosti jemocional'nogo vygoranija studentov pedagogicheskogo vuza i ego profilaktika s pomoshh'ju tajm-menedzhmenta [Features of emotional burnout of students of a pedagogical university and its prevention using time management] /Ju.V. Skorobogatova// Perspektivy nauki i obrazovanija. - №2(38). - S. 284-294 (in Russian).

5. Slepcova M.V., Popova O.N. (2014) Adaptacija budushhih uchitelej tehnologii k professional'noj dejatel'nosti [Adaptation of future technology teachers to professional activities] /M.V. Slepcova, O.N. Popova// Uchebno-metodicheskoe posobie dlja samostojatel'noj raboty studentov, obuchajushhihsja po magisterskoj programme «Professional'noe obrazovanie». - Voronezh: Izd-vo VGPU. - $76 \mathrm{~s}$ (in Russian).

6. Zeer Je.F. (2003) Psihologija professij [Psychology of professions] / Je.F. Zeer. - M.: Akademicheskij Proekt; Ekaterinburg: Delovaja kniga. - 336 s (in Russian).

7. Bezjuleva G.V. (2008) Psihologo-pedagogicheskoe soprovozhdenie professional'noj adaptacii uchashhihsja i studentov [Psychological and pedagogical support of professional adaptation of pupils and students] / G.V. Bezjuleva. - M.: NOU VPO Moskovskij psihologo-social'nyj institut. - 320 s (in Russian).

8. Tarhan L.Z. (2008) Didakticheskaja kompetentnost' inzhenera-pedagoga: teoreticheskie i metodicheskie aspekty [Didactic competence of an engineer-teacher: theoretical and methodological aspects] / L.Z. Tarhan. - Simferopol': KRP «Izdatel'stvo «Krymuchpedgiz». - 424 s (in Russian).

9. Boltivec' C.I. (2010) Ukrai'nc'ka pcyxologichna terminologija: clovnyk-dovidnyk [Ukrainian Psychological Terminology: Glossary] / ukl. C.I. Boltivc', N.V. Clobodjanyk, M.-L.A. Chepa, N.V. Chepeljeva. - K.: DP «Informacijno-analitychne agentctvo». - 302 c (in Ukrainian).

10. Shhelkunova L.A. (2018) Problemy professional'noj adaptacii studentov na pedagogicheskoj praktike [Problems of professional adaptation of students in teaching practice] [Jelektronnyj resurs] / L.A. Shhelkunova. URL: https://cyberleninka.ru/article/n/problemy-professionalnoy-adaptatsii-studentov-napedagogicheskoy-praktike (in Russian).

11. Danilenko O.I., Nosova A.S. (2020) Jekzistencial'naja ispolnennost' i social'no-psihologicheskaja adaptirovannost' kak prediktory sub\#ektivnogo blagopoluchija studentov [Existential fulfillment and sociopsychological adaptation as predictors of students' subjective well-being] /O.I. Danilenko, A.S. Nosova// Perspektivy nauki i obrazovanija. - №4(46). - S. 315-325 (in Russian).

12. Andrienko O.A. (2018) Professional'naja adaptacija studentov vuza v period prohozhdenija proizvodstvennoj praktiki [Professional adaptation of university students during the period of practical training] /O.A. Andrienko// Perspektivy nauki i obrazovanija. Mezhdunarodnyj jelektronnyj nauchnyj zhurnal. - №4(34). - S. 84-88. Rezhim dostupa - pnojournal.wordpress.com/archive18/18-04 (in Russian).

13. Andrienko O.A. (2018) Issledovanie udovletvorennosti studentov izbrannoj professiej [Study of student satisfaction with their chosen profession] /O.A. Andrienko// Psihologija, sociologija i pedagogika. 2016. - №7. [Jelektronnyj resurs]. URL: http://psychology.snauka.ru/2016/07/7010 (in Russian).

14. Rean A.A., Kolominskij Ja.L. (1999) Social'naja pedagogicheskaja psihologija [Social educational psychology] / A.A. Rean, Ja.L. Kolominskij. - Piter Kom. - 416 s (in Russian).

15. Kon I.S. (1984) V poiske sebja: Lichnost' i ee samosoznanie [Finding Yourself: Personality and Self-Consciousness]. I.S. Kon. - M.: Politizdat. - 335 s (in Russian).

Резюме

Козак О. Ю. Уманский государственный

педагогический университет имени Павла Тычины

ПРОИЗВОДСТВЕННАЯ ПРАКТИКА КАК ПСИХОЛОГИЧЕСКИЙ ИНСТРУМЕНТ АДАПТАЦИИ БУДУЩИХ ПЕДАГОГОВ К ПРОФЕССИОНАЛЬНОЙ ДЕЯТЕЛЬНОСТИ

Статья посвящена обоснованию основных подходов к успешной адаптации будущии педагогов $к$ профессиональной деятельности в условиях учреждения высшего образования. Раскрываются процессуально-содержательные аспекты производственной практики как психологического инструмента преодоления психологических препятствий на пути к адаптации будущих педагогов к профессиональной деятельности.

Ключевые слова: адаптация; будущие педагоги; производственная практика; профессиональная деятельность; учреждение высшего образования. 


\section{Питання психології}

\section{Summary \\ Kozak O. Uman state Pavel Tychyna Pedagogical University}

\section{PRODUCTION PRACTICE AS A PSYCHOLOGICAL TOOL FOR ADAPTATION OF FUTURE TEACHERS TO PROFESSIONAL ACTIVITY}

Introduction. The modern school has an urgent need for young teachers who are able to adequately respond to changes in the educational situation, the specifics of pedagogical systems, new conditions of professional activity. Therefore, the preparation of students for professional activity in the growing demands of the educational system, able to successfully adapt to modern socio-cultural conditions, is becoming increasingly important.

Purpose. Substantiation of the main approaches to successful adaptation of future teachers to professional activity in the conditions of higher education institution.

Methods. To achieve the goal and achieve the objectives of the study used a number of theoretical and empirical methods: theoretical - analysis, synthesis, generalization, comparison and systematization of Ukrainian and foreign scientific developments in psychological sources on the problem of adaptation of future professionals to professional activities; empirical - testing, surveys to study the psychological features of the formation of structural components and mechanisms of the studied psychological formation.

Originality. Theoretical analysis of the notion "professional adaptation» is made, the features, difficulties and phases of the given process have been disclosed. The research results are presented with a view to investigate the peculiarities of professional adaptation in students during the period of their productive practice at school. Students faced with difficulties in their work, distress arising in pedagogical activities, professional and pedagogical orientation and the level of its distinction. The results of conducted research witness the requirement in systemic preparation of the future pedagogical specialists to their professional activities, including commitments targeted to professional culture formation, as well as social and psychological trainings in positive professional behavior.

Conclusion. It is pedagogical practice that has great potential for the formation of an internal attitude to the pedagogical profession. In the process of practice the process of professional development of the future teacher, his self-education and self-education is intensified, the degree of professional readiness and suitability for pedagogical activity, the level of pedagogical orientation is checked. The activity of students during practice is analogous to the professional activity of a teacher, which is adequate to the content and structure of pedagogical activity and is organized in the real conditions of the new Ukrainian school.

Key words: adaptation; future teachers; internship; professional activity; institution of higher education.

Recelved/Поступила: 28.1020 